\title{
Urban Water Supply, Wastewater, and Stormwater Considerations in Ancient Hellas: Lessons Learned
}

\author{
A. N. Angelakis ${ }^{1,2}$, N. Mamassis ${ }^{3}$, E. G. Dialynas ${ }^{4} \&$ P. Defteraios ${ }^{3}$ \\ ${ }^{1}$ Institute of Iraklion, National Foundation for Agricultural Research, Iraklion, Greece \\ ${ }^{2}$ Hellenic Union of Municipal Enterprises for Water Supply and Sewage, Larissa, Greece \\ ${ }^{3}$ Department of Water Resources and Environmental Engineering, School of Civil, Engineering, National \\ Technical University of Athens, Zographou, Greece \\ ${ }^{4}$ DIALYNAS SA Environmental Technology, Nea Alikarnasos, Crete, Greece \\ Correspondence: N. Mamassis, Department of Water Resources and Environmental Engineering, School of Civil, \\ Engineering, National Technical University of Athens, Heroon Polytechneiou 5, GR 15780 Zographou, Greece. \\ E-mail: nikos@itia.ntua.gr
}

Received: March 5, 2014 Accepted: April 15, 2014 Online Published: May xx, 2014

doi:10.5539/enrr.v4n3p95 URL: http://dx.doi.org/10.5539/enrr.v4n3p95

\begin{abstract}
Urban water, wastewater and stormwater management practices in ancient Hellas, from the Minoan to the Roman times are briefly reviewed. In the Prehistoric Hellas palaces and other settlements tended to be located at dry places, at a distance from rivers or lakes. During the Bronze Age decentralized water supply and wastewater and stormwater management of small-scale systems were dominant. These systems are characterized by their salient architectural and hydraulic features and perfect adaptation to the environment. On the other hand, under tyranny, cities grew significantly and the first large-scale urban water infrastructures were developed. During the periods of democracy the Hippodameian system of city planning included the public hydraulic works. This period is also characterized by significant scientific progress in the hygienic use of water in public baths and latrines. Finally, Romans used the scientific knowledge and the experience of small scale constructions of the Hellenes, to construct large scale hydraulic works using sophisticated techniques.
\end{abstract}

Keywords: urban water supply; classical and Hellenistic periods; Minoan Crete; Mycenaean civilization; prehistoric Hellas

\section{Prolegomena}

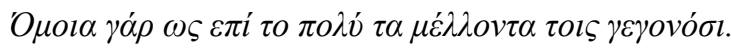

Most future facts are based on those in the past.

Euripides, 480 - 406 BC, Ancient Greek Tragic.

In the long history of humankind the basic force that determined his action was the need to secure food and water. Most of the early settlements of the humankind were established in temperate areas near water sources that ensured sufficient water supply.. Most excavations of prehistoric human habitations had one thing in common; all were located near sources of a spring, river, lake or stream. During the Neolithic age (ca. 5700 - 3200 BC), the first water projects (such as dams and irrigation systems) were developed in Mesopotamia and Egypt, in order to control the water flow, due to the food needs (Angelakis et al., 2013).

However, the first hydraulic works for water supply and wastewater management were constructed during the Neolithic Age (a) in El Kowm (or Al Kawm), located near the city of Palmyra, in Syria, and (b) in the eastern Crete, Hellas. In these locations the first domestic infrastructures for water and wastewater were built. At the end of the 4th millennium BC to the beginning of the 3rd millennium BC the early Mesopotamian cities had networks of wastewater and stormwater drainage. Also wastewater disposal facilities, such as drainage networks, were available in the Late Urak Period (ca. 3300 - 3200 BC) at Habuba Kabira. Minoan regions (e.g. Crete and other Hellenic islands) and Mohenjo-Daro (in modern day Pakistan in the Indus Valley) are early examples of settlements with water supply and sanitation. These hydraulic works were developed in an impressive way since the Bronze Age (ca. $3200-1100$ BC). Archaeological and historical evidences, revealed a cultural explosion 
unparalleled in the history of other ancient civilizations that occurred in various Minoan regions of ancient Hellas starting $c a .3200$ BC. In these sites they have survived remarkable architectural and hydraulic infrastructures for the management of urban water, stormwater and wastewater sewerage in palaces and cities (Angelakis \& Spyridakis, 2013).

Further development of Minoan hydro-technologies was achieved during the Mycenaean kingdoms ( $c a$. $1900-$ $1100 \mathrm{BC}$ ). These technologies include (a) considerable hydraulic constructions (dams, polders and levees), (b) aqueducts for conveyance and (c) water drainage and sewerage systems. However, the scientific view of hydrological phenomena were formulated only $c a$. $600 \mathrm{BC}$ in ancient Hellas by Ionian philosophers, when scientific theories, ideas and philosophical views appeared. The technological developments were driven by the necessity to (a) use efficiently the natural resources, (b) protect the civilizations from destructive natural elements, and (c) improve the quality of life, both at the private and public level.

Hellenic civilizations developed an advanced, comfortable and hygienic way of life, as expressed by public and private bathrooms and flushing toilets, that can be compared to the modern ones.. In this article a brief review of the water supply and sanitation technologies developed by the major Hellenic civilizations in the ancient Hellas is presented.

\section{Prehistoric Hellas (ca. 3200 - 1100 BC)}

In Minoan Crete many works for water supply, sewerage, and drainage systems were planned and constructed to serve the needs of the increasing population of the island (De Feo et al., 2011; Mays et al., 2007) The major hydro technologies developed during the Minoan Era, at the scale of palace, city, and village, include: (a) potable water systems, aqueducts, harvesting of rainwater systems, and network of terracotta pipes located beneath the palace floors in Knossos (Figure 1a) and Pyrgos Myrtos (Figure 1b); (b) wastewater and storm water sewage systems, like those found at Knossos, Zakros and Phaistos palaces; and (c) hygienic water use systems, like bathrooms with flushing toilets (Angelakis et al., 2005; Angelakis and Spyridakis, 2013).

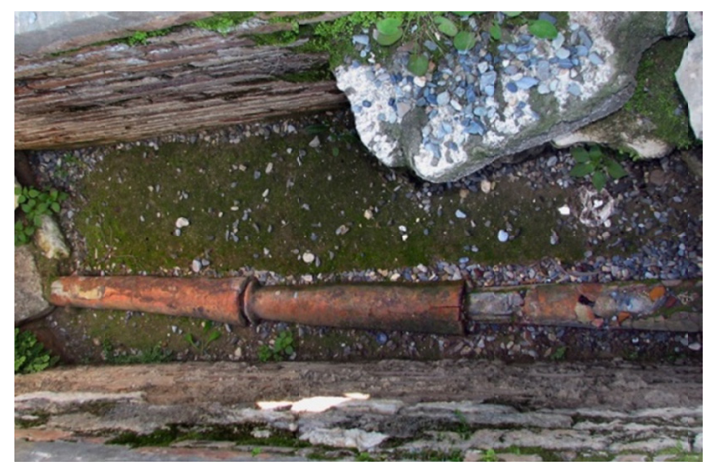

(a)

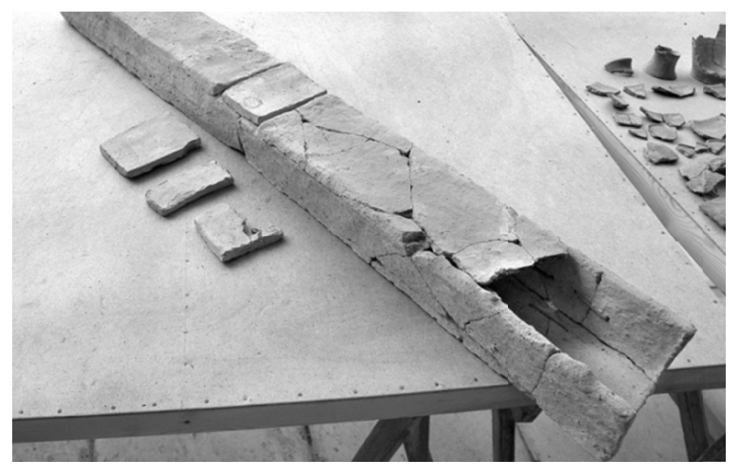

(b)

Figure 1. Terracotta pipes: (a) part of closed Minoan water supply system at the Knossos «palace» in Crete and (b) pipes of rectangular section used for collection of rain water in the Pyrgos Myrtos in the south eastern Crete (by permission of A. N. Angelakis)

Different management techniques were applied to ensure the water supply as: (a) use of spring and runoff water locally and (b) transportation and storage of water. These techniques were differentiated according to local hydrogeological conditions and the size of the settlements. Also during Minoan times the focus of water and wastewater management was on sustainable small-scale, water safety, cost efficient, and friendly to the environment management practices.

The hydraulic technological frame of prehistoric Hellas formed very early, during the Minoan/Cycladic eras and later was extended in the main land by Mycenaean civilization during its flourish period (ca. $1600-1200 \mathrm{BC})$. The scale of water systems was changed from small scale such as hydraulic works for domestic use at Minoan palaces to large scale works of the Mycenaean era that targeted to agricultural water use (irrigation and drainage). 


\section{Archaic Hellas (ca. 630 - 490 BC)}

During that period, trade became an important activity and new cities were established near the sea or the trade routes. Some of the new cities were established in dry places at a distance for water resources (lakes or rivers) so attention had to be paid for water adequacy. During that period Agora (market) was the core of the city and not the palace or the Acropolis. Gradually Agora transformed to the centre not only for the commercial activities but also for political and social ones. Gradually hygienic technologies were implemented on the scale of Agora and as the cities grew considerably the first large-scale hydraulic works were constructed. Examples of major projects during this era are: (a) the Peisistratean aqueduct which transferred water from the Hymettus mountain, to the centre of the city near Acropolis, (b) the water supply system of ancient Samos, that includes the "Eupalinean digging" (Figure 2), a tunnel of $1036 \mathrm{~m}$ long, that Eupalinos (an engineer from Megara) designed and constructed it (Koutsoyiannis et al., 2008). Its construction started in $530 \mathrm{BC}$ and lasted in ten years. It was in operation until the 5th century AD.

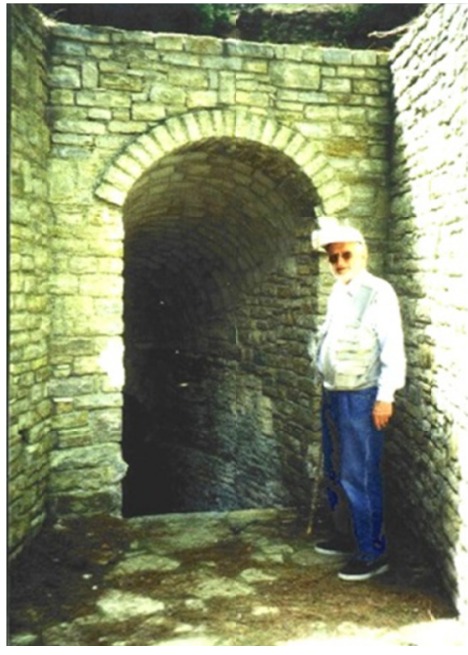

(a)

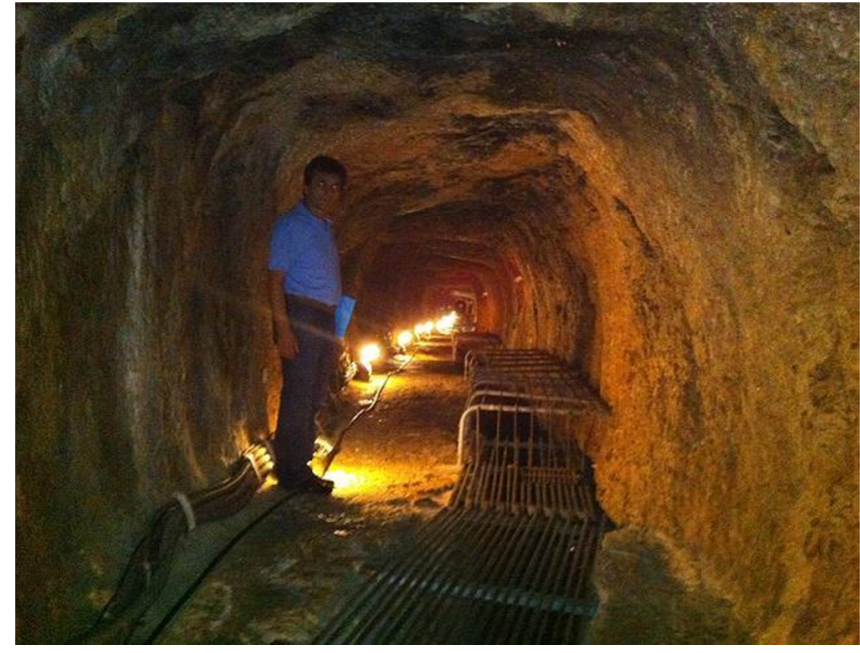

(b)

Figure 2. A view of the tunnel of Eupalinos aqueduct: (a) its entrance and (b) the sloped channel (and at points second tunnel below the main tunnel) on the right side

It is remarkable that the first Hellenic cities were established in areas that with minimal rainfall (e.g. dry and water scarce sites), in contrast to other ancient civilizations (e.g. Egyptian, Mesopotameans, and those in Indus valley) which flourished in water-abundant environments (large river valleys). Although there are wet places and relatively large rivers in Greece, Hellenes must have progressively assimilated the fact that dry climates are generally more convenient and healthier to live as they protect the population from water-borne diseases.

\section{Classical Hellas (ca. 490 - 323 BC)}

During Classical era several aqueducts were constructed in ancient cities but the hydro-technologies remain the same and the new technical developments are scarce (De Feo et al., 2013). However, emphasis was given in water management practices, mainly in the city of Athens, that flourished during that period. The introduction of the Hippodameian system in city planning influenced significantly the urban water systems, from this period up to modern times (Zarkadoulas et al., 2012).

Also, during that period Alcmaeon of Croton (floruit ca. $470 \mathrm{BC}$ ) was the first "doctor" that he stated "the quality of the water may influence the health of the people" (Aëtius, on the opinion of the philosophers $\mathrm{V} .30 .1$ ). In addition, the Hippoctratic treatise: Airs, Water, Places (ca. 400 BC) describes thoroughly the different sources, qualities and health effects of water (Airs, Water, Places. 1, 7, 8, and 9). Other Hippoctratic treatises, written at the same time, contain comments on the influence of water on the health of people.

The Peisistratean and Eupalinean water supply technologies were further improved during the Classical and Hellenistic times. The engineering solutions were improved and applied in many areas; New aqueducts were constructed more efficiently and convey water from more distant sources. The aqueducts, that capture underground water, followed by the surface transport of water (Voudouris et al., 2013). The significant characteristics of the Athens water supply system in the Classical period were the sustainability and durability. 


\section{Hellenistic Hellas (ca. 323 - 31 BC)}

Following a period with wars and conflicts, finally peace was prevailed during the Hellenistic period. The cities that had been destroyed were rebuilt, usually at the same site. In most cases, the Hippodameian system of city planning was adopted. During that period a significant scientific progress was achieved and large scale public works (such as aqueducts and cisterns), were constructed, resulting to water adequacy. The hygienic use of water in public baths and lavatories became possible for all citizens that had access to "luxurious" water usage. At the same time, the principles of integrated water management, as implemented during Classical period, started to be forgotten. In Athens, water treatment changed completely as can be inferred from the way that the spill of the fountain was dealt with. The comparison of the waste conduits that belong to these two periods leads to the conclusion that the operation of the system was different. During Classical period the overflowing water was not disposed but kept for some other purpose. On the other hand during Hellenistic era larger pipes were installed in order to cover the increased supply of water in the Agora diminishing the need for overflow. Also during the same period, private installations, like wells and cisterns, tended to be abandoned (Zarkadoulas et al., 2012).

In the Hellenistic world, the prevalence of the Hippodameian system resulted in reduced importance of security in city planning. The following comment by Aristotle is related to that issue:

The arrangement of the private dwellings is thought to be more agreeable and more convenient for general purposes if they are laid out in straight streets, after the modern fashion, that is, the one introduced by Hippodamus; but is more suitable for security in war if it is on the contrary plan, as cites used to be in ancient times; for that arrangement is difficult for foreign troops to enter and to find their way about in when attacking. Hence, it is well to combine the advantages of both plans, and not to lay out the whole city in straight streets, but only certain parts and districts, for in this way it will combine security with beauty [Aristotle, Politics, VII, X, 4, Zarkadoulas et al. (2012)].

Two aqueducts of the Hellenistic period (from the end of 4th to the end of 1st century BC) have been restored and reused during the Roman times, being still in use today in Polyrrhenia city in western Crete (Voudouris et al., 2013). They are carved by tunneling through natural marbled limestones on the southern low slopes of the city. The first aqueduct (tunnel) ends in the modern village central square (Figure 3a). In the southeastern edge of the modern settlement, there is the end of another similar tunnel (Figure 3b). Both tunnel, were constructed roughly in the same way and are used to supply the village with a continuous flow of water all year long. These aqueducts are referred as aqueducts-like qanats (Voudouris et al., 2013).

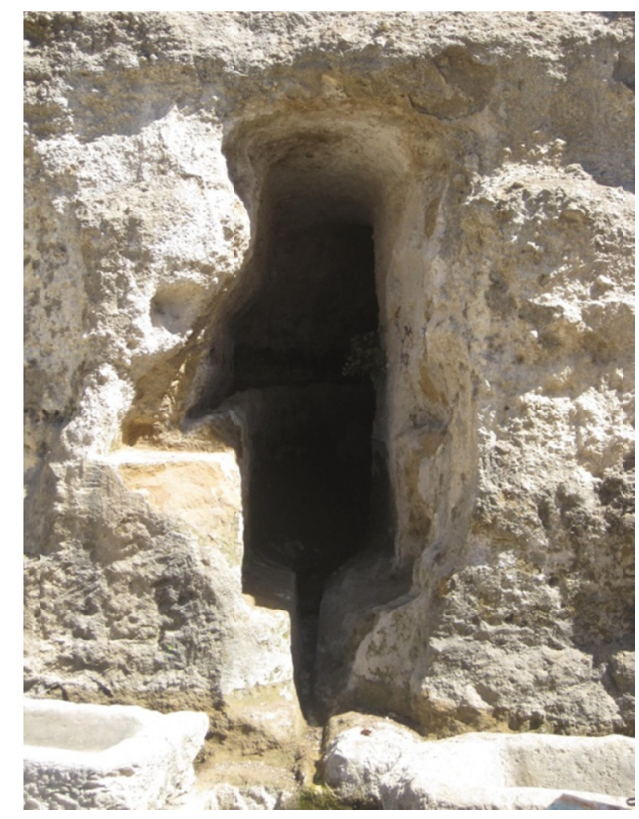

(a)

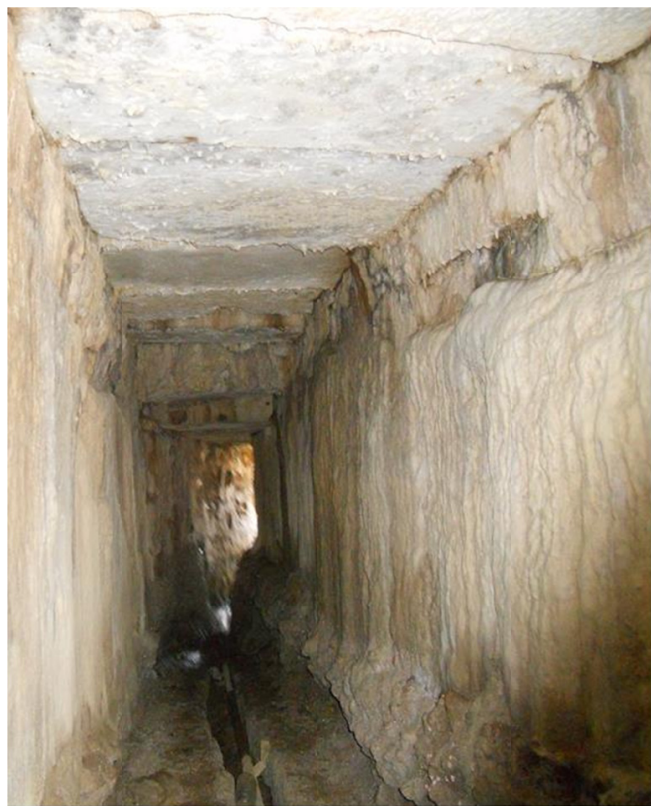

(b)

Figure 3. The two aqueducts (tunnels) in Polyrrhenia city: (a) Rock-cut cistern at the end of the first aqueduct and (b) Tunnel of the second aqueduct, with channel along the semicircular tower of the Hellenistic wall

(Christodoulakos \& Markoulaki, 2011) 


\section{Roman Hellas (ca. $31 \mathrm{BC}-395 \mathrm{AD})$}

Many important and monumental constructions were made during Roman period in conquered Hellas, as a part of a culture based on artistic and structural features of flourishing Hellenic ancient centuries (Angelakis et al. 2013). Aqueducts that were constructed in specific sites of the country, could be classified in a separate category of the monuments of this period, being in many cases successful feats of ancient engineering (De Feo et al., 2010; De Feo et al., 2013).

Romans constructed the works to supply water to each Roman town, usually channeling the required quantities from the nearest sources, which abstained up to tens of kilometers from. The construction of the water line was different along the axis, depending on the terrain. As a basic rule, the aqueduct had to maintain a gentle inclination $(0.1 \%$ or $0.2 \%)$, so that water can be transported all the way by gravity. Thus, the conduit was a shallow trench in the more parts, but wherever there were valleys or river beds, that it was constructed upon water bridges. Finally the water crossed hills, passing through tunnels.

The construction methods of surface and subterranean works were depended on soil quality of each area. In rocky soils (limestone) channels were carved above or below the surface. On the other hand, surface channels, underground channels with supported roof, or channels at shallow depths that used to be covered by stone slabs, were built wherever the soil was loose. Also, the ceramic elements were necessary structural material, and the use of mortar was required. At the construction of a water bridge, stone or ceramic briquettes were used. The bridges were consisted of columns that need to support the conduit, at distance of about $5 \mathrm{~m}$, forming arches.

In many cases, Roman aqueducts supplied more water than the amount necessary for their daily needs, because the water was also used for hygienic reasons. The bath for instance was a daily habit for Romans. Thus, many Roman public baths have been discovered in the central districts, such as the hypocaust in the basement of the Russian Church in Athens or in regional agglomerations (Rafina), even in rural areas or islands such as the town of Sami in Kefalonia. In any case, the water was available at the place of use through distribution systems, including piping and tanks at the end or along the route of the aqueduct. Furthermore, in some cases there was tank near the springs in order to control the pressure.

In Hellenic land, there are several Roman aqueducts and the most important are those of Corinth, Nicopolis, Mytilene, Patras, Thessaloniki, Eleusis and Athens. In addition, the aqueducts of Kavala and Halkida, which repaired during the Ottoman occupation, were constructed during the Roman period.

It is worth to examine with more detail the famous Hadrianean aqueduct of Athens. Its construction started by Hadrian, but the project completed by Antoninus (140 AD), aiming to supply water to the Roman district of Athens. This aqueduct differs totally from all other of the Roman period, because it was constructed subterranean all along its route. The Hadrianean is a project based on technology of earlier times aqueducts of Hymettus, Megara and Aegina (Chiotis \& Marinos, 2012). The water flowed from Parnitha springs into the tunnel, but the aqueduct also collected underground water along its route. For this reason, it was dug under the level of the water table and the amount of collected water increased along the path. Additionally, the discharge was complemented from assistant aqueducts that carried water from other regions. So we can conclude that the Hadrianean was an eclectic aqueduct which was enriched by underground waters and spring water (Chiotis \& Chioti, 2011). The main underground axis was about $20 \mathrm{~km}$ long (or $25 \mathrm{~km}$ taking into account the secondary branches). Two surface channels carried the water of Parnitha at Dimogli (Olympic Village today), where an inclined gallery had to direct the total quantity into the tunnel, at a depth of $30 \mathrm{~m}$. The tunnel was constructed by wells opened at a fixed distance of about $35 \mathrm{~m}$ between. Some impressive construction details of the carved underground tunnel (coated or uncoated) highlight the magnificent task, such as collecting water from the walls, the mounting of the roof, and the flow rate control through local level depression or small shaft incurvation. Some of the tunnel technical characteristics are depicted in Figure 4. The water was distributed through a piping system, starting from the main tank at Kolonaki, which was filled by the supply line. Hadrianean surpassed all aqueducts of the Roman time in terms of operation and construction. This is confirmed by the fact that the aqueduct was in use until 1930, for Athens water supply. However, its operation was not continuous over the centuries, as it was repaired and expanded before being restarted, after the end of Ottoman rule (early 20th century). It is still in use until today, watering the public land areas that the tunnel runs through. 


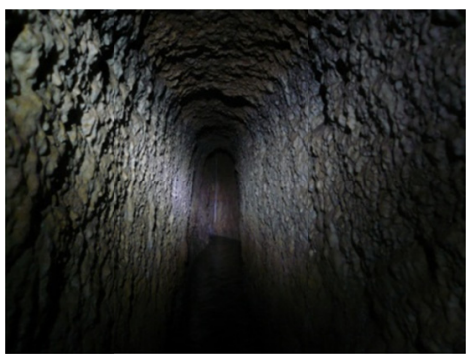

(a)

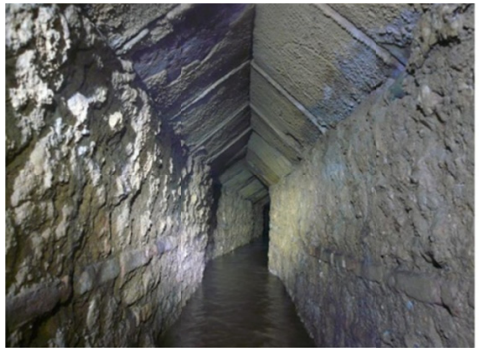

(b)

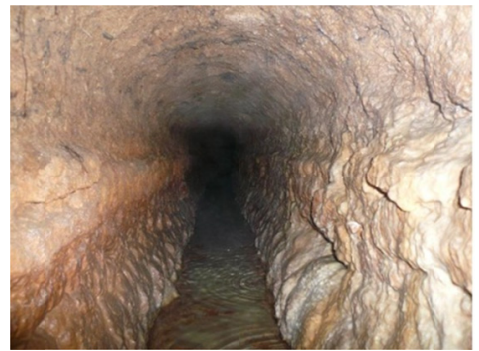

(c)

Figure 4. Technical characteristics of Hadrianean tunnel (a) Uncoated cross section (b) Cross section with masonry walls and triangular roof from ceramic slabs, (c) Cross section with masonry walls and uncoated roof (by permission of P. Defteraios)

\section{Epilogue}

From the Minoan era, constructive and operation experience in urban hydraulic works, existed in Hellas. The basic technological methods of the Minoan and Mycenaean period have been the cornerstones of the technological progress in hydraulic works and water resources management of the centuries that followed. The stagnancy during the Dark Ages was followed by significant progress in the Archaic Hellas. Hellenic hydro technological achievements were not totally forgotten during the Dark Ages. Probably 'bridges' from the past to the future are always present, albeit oftentimes invisible to those who cross them (Angelakis \& Spyridakis, 2013). During Archaic period, city-states were constructed and first urbanization occurred. As cities were dependent on trade and not on agricultural production, they tended to be located at dry places, at a distance from rivers or lakes. Under tyranny, cities grew significantly and the first large scale urban water infrastructures were developed.

The next period of democracy, that includes the construction of small-scale works and the use of non-structural measures, is a paradigm of sustainable water management and marks the consideration of the institutional progress in water issues. During the Classical and Hellenistic periods, urban city planning acquired a new dimension in the form of the Hippodameian city, which implemented a different design philosophy. The evolution of the designed city is mainly reflected on the scale of water and wastewater projects, which resulted in water adequacy and more widespread hygienic water use (Zarkadoulas et al., 2012).

The scale of the modern city is much greater compared to the antiquity and that is reflected to the scale of hydraulic works and water infrastructures. Although a direct comparison is not possible, we can assume that the following elements of ancient water management should be re-considered: (a) city planning has to include urban water and wastewater criteria; the flood protection should be a major consideration, (b) the cooperation of small-scale infrastructures, with the large-scale ones, was a big step towards sustainability and resilience, (c) the sustainable water use principles and practices, must not be forgotten even in periods of water adequacy, and (d) safety and security of water supply in emergency situations, including turbulent and war periods, should be kept in mind when designing urban water, sewerage and drainage systems.

Hellenic hydraulic technologies were further developed, mainly by enlargement of the scale of water supply and wastewater and stormwater systems, reached their peak in the Hellenistic period (that follows the reign of Alexander the Great), when they spread over a geographical area from Hellas to India to the east and Egypt to the south. The Romans, whose Empire came after the Hellenic rule in this area, inherited these technologies and developed them further mainly by changing their scale from small to large and applying them to almost every large city as in Aptera and Athens (Figure 5). 


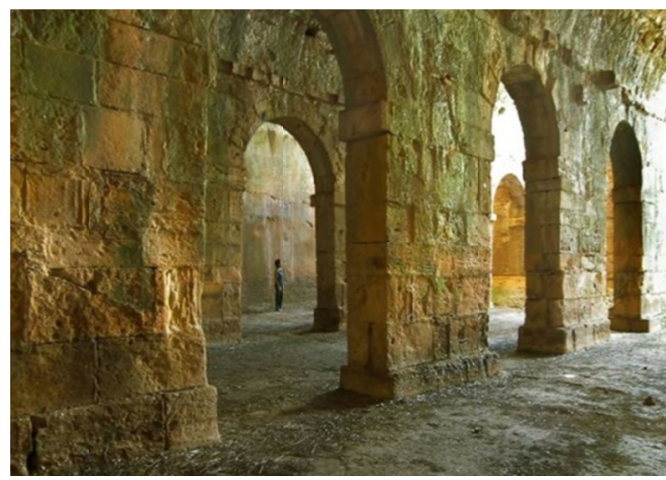

(a)

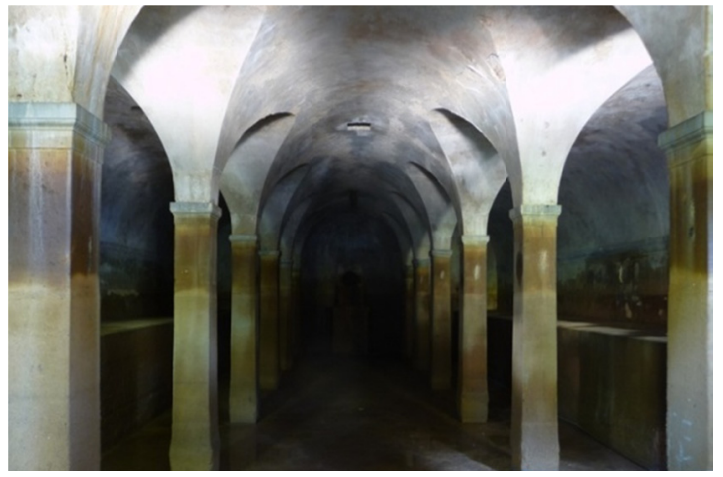

(b)

Figure 5. Interior view of Roman cisterns: (a) the three- aisled vaulted cistern in the ancient town Aptera in western Crete (by permission of A. N. Angelakis) and (b) the Hadrian in Athens, as it was rebuilt after the original design in the 1880s (by permission of P. Defteraios)

Finally, the rapid technological progress during last century created a disdain for the past achievements. Ancient water technologies were considered as obsolete, related to the modern ones. At the same time, a great number of unresolved water problems are related to management practices. The protection from floods and droughts with confidence is strongly related with the durability and sustainability of the water projects, the decentralization of the various processes, and the cost effectiveness. In the developing world, water problems are intensified following the population increase. Also, new problems have arisen such as the contamination water resources. The accumulation of unresolved problems led societies to reconsider the old practices and to reinvestigate the past technological achievements. The extensive research that based on archaeological, historical, and technical evidence, revealed the similarity of principles and solutions with present ones and the advanced level of water management. Thus, today is well documented that many of the technological principles related to hydraulic works were discovered three to four thousand years ago. However, the development of water science and engineering from the past to the present appears to be non-linear, often characterized by discontinuities and regressions.

Considering the ancient Hellas water technologies, the following issues must be emphasized:

- ancient Hellenes lived in harmony within their dry environment;

- city planning has to include urban water criteria (e.g. water supply networks, sewerage systems, and especially protection from floods infrastructure).

- decentralize water, wastewater, and storm water management in connection of the use of small-scale infrastructures, is a big step towards sustainability.

- safety and security of water supply in emergency situations, such as war periods, should be taking into account in our designs of urban water systems.

- the principles and practices of sustainable water use should not be forgotten even in periods of high water availability.

- ancient Hellenic water and wastewater practices are relevant even today, as the water related problems of modern societies are not very different from those times (e.g. water cisterns for harvesting rainwater in order to increase water availability and reduce the flood risks).

Today, more than 2.6 billion people do not use improved sanitation and 1.1 billion practice open defecation. Also 1 billion people have limited access to drinking water. Thus there is a huge need for sustainable and cost-effective water supply and sanitation facilities, particularly in cities of the developing world (Bond et al., 2013). Lessons from ancient water management must be examined and the applicability of selected ancient Hellenic systems to the contemporary world must be considered.

\section{References}

Angelakis, A. N., Yun, Z. X., \& Koyuncu, I. (2013). Editorial: Probing the past and facing the future. Water Sci. and Techn.: Water Supply, 13(3), 561-563. http://dx.doi.org/10.2166/ws.2013.151

Angelakis, A. N., \& Spyridakis, S. V. (2013). Major Urban Water and Wastewater Systems in Minoan Crete, 
Greece. Water Sci. and Techn.: Water Supply, 13(3), 564-573. http://dx.doi.org/10.2166/ws.2013.091

Angelakis, A. N., Koutsoyiannis, D., \& Tchobanoglous, G. (2005). Urban Wastewater and Stormwater Technologies in the Ancient Greece. Water Res., 39(1), 210-220. http://dx.doi.org/10.1016/j.watres.2004.08.033

Angelakis, A. N., De Feo, G., Laureano, P., \& Zourou, A. (2013). Minoan and Etruscan Hydro-Technologies. Water (Switzerland), 5(3), 972-987. http://dx.doi.org/10.3390/w5030972

Bond, T., Roma, E., Foxon, K. M., Templeton, M. R., \& Buckley, C. A. (2013). Ancient water and sanitation systems - applicability for the contemporary urban developing world. Water Sci. and Techn., 67(5), 935-41. http://dx.doi.org/10.2166/wst.2013.628

Chiotis, D. E., \& Marinos, G. P. (2012). Geological aspects on the sustainability of ancient aqueducts of Athens. Bulletin of the Geological Society of Greece, XLVI, 16-38.

Chiotis, E., \& Chioti, L. (2011). Industrial activities in the Ancient Agora of Athens in the Late Roman times. In A. Giannikouri (Ed.), The Agora in the Mediterranean from Homeric to Roman time (pp. 181-196). Athens: Ministry of Culture.

Christodoulakos, Y., \& Markoulaki, S. (2011). Water Supply of Polyrrhenia. In Proceedings of the 11th International Cretological Congress, Rethymnon, Greece.

De Feo, G., Laureano, P., Drusiani, R., \& Angelakis, A. N. (2010). Water and wastewater management technologies through the centuries. Water Science and Technology: Water Supply, 10(3), 337-349.

De Feo, G., Mays, L. W., \& Angelakis, A. N. (2011). Water and Wastewater Management Technologies in the Ancient Greek and Roman Civilizations. In P. Wilderer (Ed.), Treatise on Water Science (Vol. 4, pp. 3-22). Oxford, UK: Oxford Academic Press.

De Feo, G., Ribera, F., Abbondandolo, S., \& De Gisi, S. (2013). What lessons can be learnt from studying a Roman hydraulic structure in a little village in Southern Italy? Water Science and Technology: Water Supply, 13(3), 666-673. http://dx.doi.org/10.2166/ws.2013.002

De Feo, G., Angelakis, A. N., Antoniou, G. P., El-Gohary, F., Haut, B., Passchier, C. W., \& Zheng, X. Y. (2013). Historical and Technical Notes on Aqueducts from Prehistoric to Medieval Times. Water, 5, 1996-2025.

Koutsoyiannis, D., Zarkadoulas, N., Angelakis, A. N., \& Tchobanoglous, G. (2008). Urban Water management in Ancient Greece: Legacies and Lessons. ASCE. Journal of Water Resources Planning \& Manag., 134(1), 45-54. http://dx.doi.org/10.1061/(ASCE)0733-9496(2008)134:1(45)

Mays, L. W., D Koutsoyiannis, D., \& Angelakis, A. N. (2007). A Brief History of Water in Antiquity. Water Sci. and Techn.: Water Supply, 7(1), 1-12.

Voudouris, K., Christodoulakos, Y., Stiakakis, M., \& Angelakis, A. N. (2013). Hydrogeological Characteristics of Hellenic Aqueducts-like Qanats. Water, 5, 1326-1345. http://dx.doi.org/10.3390/w5031326

Zarkadoulas, N., Koutsoyiannis, D., Mamassis, N., \& Angelakis, A. N. (2012). A Brief History of Urban Water Management in Ancient Greece. Evolution of Water Supply throughout Millennia (Ch. 10, pp. 259-270). London, UK: IWA Publishing.

\section{Copyrights}

Copyright for this article is retained by the author(s), with first publication rights granted to the journal.

This is an open-access article distributed under the terms and conditions of the Creative Commons Attribution license (http://creativecommons.org/licenses/by/3.0/). 